\title{
The Use of the Case Method to Promote Reflective Thinking in Teacher Education
}

\author{
Wei-Yu Liu \\ Professor \\ Department of Education and Potential Development \\ National Dong Hwa University, Taiwan \\ Pin Chen \\ Master Student \\ Department of Counseling \& Clinical Psychology \\ National Dong Hwa University, Taiwan
}

\begin{abstract}
This research introduces and reflects on the utilization of case study method in the field of teacher education to explore how case study method impacts students' reflective thinking towards education issues. Over the duration of study, an action research was conducted in the Education Issue course of teacher education program in a National University. Two case videos and the following discussions were used as tools to enhance students' reflective thinking towards the assigned issues. The result of this study shows that case study method might not alter students' viewpoints, but it can surely enhance their degrees of reflective thinking on the assigned education issues.
\end{abstract}

Keywords: Teacher Education, Case Method, Reflective Thinking

\section{THE PURPOSE AND IMPORTANCE OF THE STUDY}

Since its inception in 1870, the father of the case study method (also called "case method," "case methods," "case study" or "case-based instruction")—Christopher Columbus Langdell never gave up on this creative pedagogic tool; though considerable resistance was aroused by his proposal to Harvard Law School at the time. According to Vande Kemp (1980), Professor Langdell's idea was then "culminating in the founding of a new law school" (p. 38). A few decades later, this unique methodology eventually revolutionized legal, business, and medical education at all major universities all around the world. The success of the case study method can be attributed to its distinctive capability on developing students' "good mental habits."

As John Dewey (1933) stated:

The most important factor in the training of good mental habits consists in acquiring the attitude of suspended conclusion and in mastering the various methods of searching for new materials to corroborate or to refute the first suggestions that occur; to maintain the state of doubt and to carry on systematic and protracted inquiry-these are the essentials of thinking. (p. 13)

In other words, it is only due to the attitude of suspiciousness that a practitioner can look critically at his/her own thinking pattern to seek ethical answers under problematic circumstances.

As a field that inculcates future teachers, it is necessary for teacher educators to bring the case study method into practice in order to make sure that there will always be highly qualified 
teachers standing in the front of classrooms to teach our children. In accordance to the above idea, Laboskey (1992) claimed, "Teaching must be both reasoned and reasonable. Teachers must be taught how to reason using substantially supported ethical, empirical, theoretical, and practical principles" (p. 177). As a pilot study, this study introduces and reflects on the utilization of the case study method in the field of teacher education and explores how it impacts students' awareness and attitude towards education issues. To illustrate the ground of this study, scholars' thoughts on why and how to implement the case study method in the field of teacher education are introduced in the following section.

\section{PERSPECTIVE}

In the arsenal of instructional strategies, as pointed out by Heitzmann (2008), teacher education was "...long criticized uninspired instruction featuring lecture, textbook and memorizing in a passive student setting on the college campus and likewise in schools" (p. 523524). Therefore, as it was later considered the pioneer in its field, Stanford Teacher Education Program (STEP) introduced the idea of the case study method to its students in the summer of 1985 as a way to mitigate the gap between theory and practice. In light of Gideonese's (1999) assertion, the major purpose of the case study method is to "...engage the perceptual, problem identification and analysis, and decision making capacities of students with the aim of honing those capacities to ever higher states of effectiveness" (as cited in Daniel, 2001, p. 4). Corresponding with Gideonese's view point, Hourigan (2006) also claimed that the case study method "...is one way to develop reflective thinking skills and enhance existing preservice music education" (p. 33).

Reflective thinking, as defined by Dewey (1933):

...is an active, persistent, and careful consideration of any belief or supposed form of knowledge in light of the grounds that support it, and the further conclusions to which it tends, constitutes reflective thought. Any one of the first three kinds of thought may elicit this type; but once begun, it is a conscious and voluntary effort to establish belief upon a firm basis of reasons. (p. 6)

To cultivate pre-service teachers' reflective thinking skills, it is important to know that in a case study classroom, "there is no one 'right' answer to the questions presented. It is safe to say though that these issues will not be answered by 'it all depends!"” (Diamantes \& Ovington, 2003, p. 469). In the process of developing reflective thinking skills, students can not only recognize their own attitudes about teaching, but also build their identities as secondary teachers.

The concept of reflection derives from Scho"n's (1983) distinction between teaching as technical rationality and teaching as problem solving. Reflection, in the problem solving context, refers to a purposeful, systematic inquiry into one's personal theories about teaching and learning and the practices guided by those theories. LaBoskey (1993) defined reflection as involving certain contexts, processes, attitudes, and contents that lead to the development of new understandings about teaching and learning and to the solving of problems of practice. Reflective teachers are able to think about their own or someone else's teaching, reframe problems, compare practice with personal theories, and take new actions (Munby \& Russell, 1992). In preservice teacher education, guided practice in reflection can help students of teaching construct their personal theories (McIntyre, 1993; Wildman, Niles, Magliaro, \& McLaughlin, 1990; Abell S. K., etc., 1997).

Based on serious research that was conducted by WestEd (formally Far West Laboratory), if implemented appropriately, the case study method can help prospective teachers develop the 
following thinking skills: a) bridge theory and practice; b) spot issues and frame problems in ambiguous situations; c) interpret situations from multiple perspectives; d) identify crucial decision points and possibilities for action; e) recognize potential risks and benefits inherent in any course of action; and f) identify and test teaching principles in real classroom situations. (Shulman, 2000, p. 4)

Furthermore, the case study method can not only help prospective teachers to "develop a sense of ethical responsibility", but also be a powerful tool aiding them to "understand the situated nature of teaching by engaging in analytical and critical reflections" (Lee \& Choi, 2008, p. 496).

When conducting a case study, Kunselman (2004) pointed out that, "students learn not only from the instructor but also from each other" because that is "where they move beyond simply memorizing to understanding course materials" (Kunselman \& Johnson, 2004, p. 87). That is to say, it is through the case discussion that students find themselves engaging in an active learning environment, which allows them to freely incorporate educational theories in real life settings. One similar notion is called "Active Learning Theory." It holds that, "students internalize information best when they are directly involved in their own learning" (as cited in Kunselman \& Johnson, 2004, p. 87). By creating an active learning environment, students can "develop problem-solving, critical reasoning and analytical skills, all of which, are valuable tools that prepare students to make better decisions and become capable thinkers and ultimately better employees" (Kunselman \& Johnson, 2004, p. 92).

However, to insure that the case study method has the above mentioned benefits, the understanding of teaching and learning would be the most significant prerequisite when applying this pedagogic tool. In stressing the importance of theoretical knowledge about teaching, Doyle (1990) asserted that "defining, selecting, designing and classifying cases" should always be considered key issues when conducting case methodology (as cited in Diamantes \& Ovington, 2003, p. 466). The absence of an instructor's knowledge of teaching and learning will eventually damage the efficacy of the case study method. Last but not least, Mostert (2007) suggested that there are two types of challenges that the case study method brings to the field of teacher education.

The first type is "Pedagogical Challenges," these include: a) unfamiliarity with case teaching; b) relating cases to a theoretical base; c) case preparation; d) case emphases; e) speculation; f) case complexity; g) strategies for introducing cases; h) teaching style of the case leader; i) participation in case discussion; j) communication in case discussions; $\mathrm{k}$ ) questioning techniques; l) focused case discussion; and m) directive teaching.

The second type is "Practical Challenges," these are: a) class size; b) time; c) problems in written expression; d) physical setting for the discussion; e) students' names; f) inexperience; g) modeling; and h) explicit teaching of access to resources (p. 436-440).

Albeit the above mentioned concerns, is the advantages of implementing the case study method in teacher education programs still outweigh its challenges? Could the use of the case method foster pre-service teachers' reflective thinking skills? This study tries to answer the above question.

\section{Participants}

\section{METHODS}

The action research took place in a teacher education classroom at National Dong-Hwa University. All participants were students registered in a pre-service teachers' course titled 
Education Issues. Among the thirty students who participated, eighteen were undergraduate students and the other twelve were graduate students. As for the participants' teaching experiences, twenty-five of them were pre-service teachers without any prior teaching experience and the other five were teachers in service and who had already been working in an educational setting.

\section{Research Design}

Most notable, this research was conducted using what has been referred to as the case study method. Sykes and Bird (1992) discovered five categories "that speak to the diversity of theory and practice surrounding the case idea." These five categories include: a) Textbook cases; b) Casebooks; c) Conversations and videotapes; d) Subject-specific cases; and e) Context-specific cases (as cited in Diamantes \& Ovington, 2003, p. 466). Noting this prior research, we chose the "Conversations and videotapes" category as the most appropriate case study tool and to use while conducting our research. According to O'Connel and his associates:

The presentation of a case protagonist via video may connect with students in ways that are expected based on their normal communication diet. In this sense, the individual in the case may be more real to students via video than through print media alone. (O'Connel, McCarthy, and Hall, 2004, p. 298)

O'Connel's assertions found video media to be an effective and appropriate media form with which we could connect our research participants with the content used later in our study. In addition to $\mathrm{O}^{\prime}$ Connell and his associates understanding, that students can make stronger connections with a case "protagonist" or hero via video rather than print media alone, Hourigan (2006) asserts that, "cases must be used to facilitate other activities, such as group discussion, role playing, and writing activities" (p. 44).

Furthermore, the work of these scholars served as the primary foundation of our research design approach while we conducted our study. All the participants were instructed to work on written assignments pertaining to the related issues that they were all assigned, in order to help them reflect on their personal experience and to prepare them for the real-world teaching situations.

In summation, the information and data gathered from case videos, case discussions and written assignments serve as the three primary tools we used to triangulate the results of our research.

\section{Procedure}

Figure 1 demonstrates the issues that were being taught in the "Education Issues" course during the semester at National Dong-Hwa University throughout the spring semester of 2009. As Table 1 depicts, during the semester, only Issue A and Issue D were introduced using case study method. In general, the case video I presented during the first week of classes and the following discussion took place during week two. After each case discussion, students were required to turn in group papers which represented their combined views about the case videos. As Hourigan (2006) indicates, "these processes will help engage students in understanding the nuances of teaching and broaden students' situational knowledge base for teaching" (p. 44). 
Table 1 List of Issues

\begin{tabular}{|c|c|l|}
\hline Week & Issues & Descriptions \\
\hline 1 & / & Course Introduction \\
\hline 2 & A & Secondary Education \& Secondary Educators \\
\hline 3 & A & Issue A Discussion \\
\hline 4 & B & The Nine-Year Compulsory Curriculum \\
\hline 5 & C & Multicultural Education \\
\hline 6 & D & Realizing Individual Differences \\
\hline 7 & D & Issue D Discussion \\
\hline 8 & E & The Twelve-Year Compulsory Curriculum \\
\hline 9 & F & High School Curriculum \\
\hline 10 & G & Teacher Education \\
\hline 11 & H & Learning Outcome Assessment \\
\hline 12 & I & Experiential Learning \\
\hline 13 & J & Innovative School Operation \\
\hline 14 & K & Teacher Evaluation \\
\hline 15 & L & Final Paper \\
\hline
\end{tabular}

Using Issue A as an example, during week two, a case video related to Issue A (Secondary Education \& Secondary Educators) shown to all the study participants. During the conclusion of this class, students were required to share their viewpoints regarding the video in groups in order to foster relevant ideas for class discussions during the following week. In week three, a list of discussion questions was distributed to students and each was then required to share their feelings and thoughts concerning Issue A. After facilitating group discussions, students were then asked to turn in group papers the following week. This process was repeated using Issue $\mathrm{D}$ and implemented in the same manner during weeks 6 and 7.

\section{Instructional Materials}

For Issue A "Secondary Education \& Secondary Educators," students were asked to watch "Teacher", a video that was published by Taiwan Public Television Service, during the class section. This one-hour long documentary explores the mainstream idea of secondary education in Taiwan and takes an in depth look at the consequences of our latest education revolution. For many decades, students were required to take entrance exams in order to get into an ideal high schools or universities. Under these circumstances, students had to work very hard to accomplish their goals due to intense competition.

However, the opportunity cost of getting into an ideal school was the confinement of childhood and adolescent experiences by a cultural doctrine that only allowed them to pursue academic aims. This case video focuses on secondary teachers' dilemma of creating an educational environment that is good for students' wellbeing both mentally and physically while also helping them to reach their academic goals.

For Issue D "Realizing Individual Differences," students were asked to watch another video, "Teaching in New Zealand-Perspectives of Taiwanese Pre-service Teachers," also published by Taiwan Public Television Service. This one-hour long documentary portrays two Taiwanese pre-service teachers' adventure in New Zealand teaching the local students.

During the course of this cultural adventure, two pre-service teachers from Taiwan experienced tremendous cultural shock while teaching New Zealander students. This was in part due to the differences in teaching methods between two countries. In contrast with 
Taiwanese' conventional teaching methods, students from New Zealand are not required to read identical textbooks when studying for a particular subject and schools do not hold a morning ceremony daily so that students can listen to their school executives' speak.

Most important, the teacher-learner relationship in New Zealand is relaxed, easy, and equal. The director of this documentary concentrates on two young Taiwanese pre-service teachers and their mental struggle while in a foreign country and their reflections about teaching and learning during their stay.

The discussion questions of both videos were: a) What are the differences between your own experiences and the main character's experiences?

b) Among those education issues that were revealed in the case video, which is the most important one according to your point of view? c) Pick one education issue that was brought up in the video and share your opinions on what has caused the problem and how to solve it? Rationales behind your opinions are required.

\section{Data Collection}

While conducting our research, an in-class questionnaire regarding students' viewpoints on each issue was distributed at the end of the semester in order to properly observe whether the change of teaching methods evoked differing levels of impact among the student participants. The questionnaire is as table 2. Also, the students' assignments regarding the two issues that were introduced using the case study method were also used as another source of interpreting students' perception concerning Issue A and Issue D. The coding system is as the follows: A01 represents Issue A No 1 student, and D40 represents Issue D No 40 student. 
Table 2 Education Issue Awareness questionnaire

\begin{tabular}{|c|c|}
\hline Topic of Issues & Awareness of related education issue \\
\hline $\begin{array}{l}\text { Issue A : Secondary Education \& Secondary } \\
\text { Educator (case method) }\end{array}$ & $\begin{array}{l}1 \text { Strongly disagree } \\
2 \text { Disagree } \\
3 \text { Neither agree nor disagree } \\
4 \text { Agree } \\
5 \text { Strongly Agree }\end{array}$ \\
\hline Issue B : Grade 1-9 Curriculum & $\begin{array}{l}1 \text { Strongly disagree } \\
2 \text { Disagree } \\
3 \text { Neither agree nor disagree } \\
4 \text { Agree } \\
5 \text { Strongly Agree }\end{array}$ \\
\hline Issue C : Multiple Cultures & $\begin{array}{l}1 \text { Strongly disagree } \\
2 \text { Disagree } \\
3 \text { Neither agree nor disagree } \\
4 \text { Agree } \\
5 \text { Strongly Agree }\end{array}$ \\
\hline $\begin{array}{l}\text { Issue D : Cultural Difference and Internship } \\
\text { Teaching (case method) }\end{array}$ & $\begin{array}{l}1 \text { Strongly disagree } \\
2 \text { Disagree } \\
3 \text { Neither agree nor disagree } \\
4 \text { Agree } \\
5 \text { Strongly Agree }\end{array}$ \\
\hline Issue F: Senior Higher School Curriculum & $\begin{array}{l}1 \text { Strongly disagree } \\
2 \text { Disagree } \\
3 \text { Neither agree nor disagree } \\
4 \text { Agree } \\
5 \text { Strongly Agree }\end{array}$ \\
\hline Issue G: Teacher Education & $\begin{array}{l}1 \text { Strongly disagree } \\
2 \text { Disagree } \\
3 \text { Neither agree nor disagree } \\
4 \text { Agree } \\
5 \text { Strongly Agree }\end{array}$ \\
\hline Issue H: Learning and Assessment & $\begin{array}{l}1 \text { Strongly disagree } \\
2 \text { Disagree } \\
3 \text { Neither agree nor disagree } \\
4 \text { Agree } \\
5 \text { Strongly Agree }\end{array}$ \\
\hline Issue I: Explore Education & $\begin{array}{l}1 \text { Strongly disagree } \\
2 \text { Disagree } \\
3 \text { Neither agree nor disagree } \\
4 \text { Agree } \\
5 \text { Strongly Agree }\end{array}$ \\
\hline Issue J: Innovative School Management & $\begin{array}{l}1 \text { Strongly disagree } \\
2 \text { Disagree } \\
3 \text { Neither agree nor disagree } \\
4 \text { Agree } \\
5 \text { Strongly Agree }\end{array}$ \\
\hline Issue K: Teacher Evaluation & $\begin{array}{l}1 \text { Strongly disagree } \\
2 \text { Disagree } \\
3 \text { Neither agree nor disagree } \\
4 \text { Agree } \\
5 \text { Strongly Agree }\end{array}$ \\
\hline Issue L: Writing Term Paper & $\begin{array}{l}1 \text { Strongly disagree } \\
2 \text { Disagree } \\
3 \text { Neither agree nor disagree } \\
4 \text { Agree } \\
5 \text { Strongly Agree }\end{array}$ \\
\hline
\end{tabular}




\section{Quantitative Data}

\section{RESULTS}

Table 3 indicates that the effect of case method on students' awareness of education issues is significantly higher than that of non case method.

Table 3: Summary of Dependent $t$ Test for Case Methods $(\mathrm{N}=30)$

\begin{tabular}{ccccccc}
\hline & \multicolumn{2}{l}{ Non-case method } & \multicolumn{2}{c}{ Case method } & Mean Difference & T \\
\cline { 2 - 5 } M & SD & M & SD & & \\
& 3.56 & 0.44 & 4.28 & 0.49 & 0.72 & $7.477^{*}$ \\
\hline
\end{tabular}

$* p<\overline{.001}$

An explanation for the positive effects can be due to the nature of case method. Previous studies showed that providing case method can engage the perceptual capacities of students and develop students' reflective thinking skills (Daniel, 2001; Hourigan, 2006).

Lee \& Choi (2008) pointed out that case method can aid prospective teachers to understand the situated nature of teaching by engaging in analytical and critical reflections. Furthermore, case method encourages students to discuss with each other, and it helps students move beyond simply memorizing to understanding course materials (Kunselman \& Johnson, 2004).

\section{Qualitative Data}

Students' assignments for Issue A Secondary Education \& Secondary Educators, demonstrated that after the videos and group discussions, participants learned that there is a considerable discrepancy of an ideal education system between policy makers and practitioners.

For many decades, students in Taiwan had to take one entrance exam to get into senior high schools and another to get into colleges or universities. It may sound easy and fair, but for students who are highly motivated to be get into prestigious schools, an imprisoned childhood was usually a price that they would have to pay until they accomplish their goals.

Therefore, an education revolution took place in hopes of creating a system that could help students pursue individual interests instead of solely seeking success on their entrance exams. Essentially, this video serves as a stimulus which helps participants to re-think the following issues: first, their definitions of highly qualified teachers and exceptional students; and second, the current education system's impact on teachers and students in real life classroom settings. Written comments indicate students' knowledge about the assigned issues. They are:

There is a huge gap between what we are being taught in this program and what is really going on in the real classroom settings (A01).

The entrance exam mechanism is always the primary foundation of our education system. It shapes how schools develop instruction policy; it dominates the mainstream ideas of excellent teachers and outstanding students; it regulates both teachers and students' proper performances in the school settings. The value of education in Taiwan is structured around the idea that students who can not pass entrance exams and get into prestigious schools are not considered as "good students" (A30).

The entrance exam mechanism has created an education environment that strangles a lot of passionate teachers by confined their instructional materials and strategies (A05). 
Written comments regarding students' reflective thinking towards the assigned issues are: What makes a qualified teacher? A teacher who urges students to accomplish academic goals? Or a teacher who cares about students' personal interests (A21)?

What is the definition of "an outstanding student" (A09, A21)?

Most students do not have chance to talk or share their opinions in the class. We need to create a learning environment which allows students to speak freely (A09).

To ensure that our education system is doing the right thing, the fundamental value of the latest education revolution should go through a re-thinking process (A08).

On the other hand, students' assignments for Issue D Realizing Individual Differences, show that after the video and group discussion, students observed that the main characters in the video had encountered two tremendous culture shocks in New Zealand: first, the teacherlearner relationship is easier and equal in New Zealand when compared with Taiwan; and second, teachers are facilitators instead of rigid or isolated authority figures in New Zealand.

The two Taiwanese young women's mental struggle to adapt within this new culture aroused a re-envisioning among the participants about a teacher's role, teaching methodology, and how the education system shapes children's futures and a country's distinguishing cultural feature. In addition, participants also realized that policies that work for western countries may not be as feasible to implement in Taiwan because of the cultural and individual differences.

All in all, an efficient education system should be built on a country's specific cultural values and students' individual needs, but not on successful examples from other countries that can not be exactly fitted with the needs of another continent. Written comments indicate students' knowledge about the assigned issues. They are:

In Taiwan, we have a lot of cram schools that help students pass all kinds of tests. And our teachers are more like authority rather than facilitators. This is very different from the education system in New Zealand. (D01)

Students from New Zealand are very different from us. They are all very active students who are really interested in what they are learning during the class section. This might have something to do with their cultural background or education policy. However, policies that work for western countries may not be feasible in Taiwan because of the cultural and individual differences. (D28, D4, D11)

I do envy students in New Zealand because they are granted a lot more freedom than we are. I'm interested in why and how the culture created that kind of education system. (D29)

Written comments regarding students' reflective thinking towards the assigned issues are: We should seriously take a deep look into our education system and ask why are there so many cram schools? Is there anything wrong with our school education? (D12)

First we need to have a real deep understanding regarding the education system in New Zealand, then we try to find out what can be copied and what cannot be copied, and carefully seek for the best way to implement the new policy in our culture. (D4) 


\section{DISCUSSION}

As mentioned in the beginning, the major purpose of implementing the case study method is to cultivate students' reflective thinking because it is only with an attitude of suspiciousness that a teacher can look critically at his/her own teaching pattern and seek for appropriate answers to problematic situations.

As a pilot study, our research introduces and reflects on the utilization of the case study method in the field of teacher education to explore how the case study method alters students' perceptions and attitudes toward certain educational issues.

Over the duration of our study, two case videos and the relevant discussions that followed were used as tools to enhance and alter students' perceptions about the assigned Issues. The result of our study shows that the case study method might not alter students' viewpoints, but it can surely enhance their degrees of awareness about the assigned educational issues.

In our teacher education program, the case study method is still considered a novel experience for both instructors and students. Hence, the inexperience in manipulating this new teaching method should be considered as the primary limitation, which diminishes the validity of this study.

For future research, a higher usage frequency is required to ensure the reliability of the research. In other words, an issue should at least be taught using the case study method for a longer period of time so this powerful tool can be shown to cultivate students' analytical and critical reflection skills in problematic situations can be developed further.

In conclusion, the topic of the case study method in the field of teacher education in Taiwan is a fertile landscape for future exploration; it holds a productive promise for qualitative researchers because of its intrinsic nature; but for the lack of significant quantitative studies available limit the credibility of this field, therefore, future research should aim to promise to illuminate the efficiency of the case study method by representing it not only with words, but also with numbers.

\section{References}

Abell S. K., Bryan L. A., Anderson, M. A. (1997). Investigating preservice elementary science teacher reflective thinking using integrated media case-based instruction in elementary science teacher preparation.

Daniel, F. (2001, August). Case studies \& methods in education. Paper presented at the annual meeting of the European Association for Research on Learning and Instruction, Fribourg, Switzerland.

Dewey, J. (1933). How we think. Buffalo, NY: Prometheus Books.

Diamantes, T. \& Ovington, J. (2003). Storytelling: Using a case method approach in administrator preparation programs. Education. 123. 465-451.

Hourigan, R. (2006). The use of the case method to promote reflective thinking in music teacher education. UPDATE: Applications of Research in Music

Education, 24, 33-44. Retrieved June 15, 2009, from Professional Development Collection database.

Kunselman, J. C. \& Johnson, K. A. (2004). Using the case method to facilitate learning. College Teaching. 52, 87-92.

Laboskey, V. K. (1992). Case Investigations: Preservice teacher research as an aid to reflection. In Shulman, J. H. (Eds.), Case methods in teacher education (pp. 175-193). New York: Teachers College Press.

LaBoskey (1993). A conceptual framework for reflection in preservice teacher education. In J. Calderhead \& P. Gates (Eds.), Conceptualizing reflection in teacher development (pp. 23-38). Washington, DC: Falmer Press.

Lee, K. \& Choi, I. (2008). Learning classroom management through web-based case instruction: Implications for early childhood teacher education. Early Childhood Education Journal, 35, 495-503. 
McIntyre, (1993). Theory, theorizing and reflection in initial teacher education. In J. Calderhead \& P. Gates (Eds.), Conceptualizing reflection in teacher development (pp. 39-52). Washington, DC: Falmer Press.

Merseth, K. K. (1992). Decision making in teacher education. In Shulman, J. H. (Eds.), Case methods in teacher education (pp. 50-63). New York: Teachers College Press.

Mostert, M. P. (2007). Challenges of case-based teaching. Behavior Analyst Today, 8, 434-442.

Munby \& Russell (1992). Frames of reflection: An introduction. In T. Russell \& H. Munby (Eds.), Teachers and teaching: From classroom to reflection (pp. 1-8). New York: Falmer Press.

O'Connel, D., McCarthy, J., \& Hall, D. (2004). Print, video, or the CEO: The impact of media in teaching leadership with the case method. Journal of Management Education, 28, 294-318.

Scho"n's (1983). The reflective practitioner. New York: Basic Books.

Sykes, G., \& Bird, T. (1992). Teacher education and the case idea. In G. Grant (Ed.), Review of research in education, $18,457-521$.

Vande Kemp, H. (1980). Teaching psychology through the case study method. Teaching of Psychology, 7, 38-41.

Wildman, N., Magliaro, \& McLaughlin (1990). Promoting reflective practice among beginning and experienced teachers. In R. T. Clift, W. R. Houston, \& M. C. Pugach (Eds.), Encouraging reflective practice in education (pp. 139162). New York: Teachers College Press. 